\title{
Comparison of a high-carbohydrate and high-protein breakfast effect on plasma ghrelin, obestatin, NPY and PYY levels in women with anorexia and bulimia nervosa
}

Dana Sedlackova 1,3,4, Jana Kopeckova ${ }^{1}$, Hana Papezova ${ }^{2,5}$, Vojtech Hainer ${ }^{1}$, Hana Kvasnickova', Martin Hill ${ }^{1}$ and Jara Nedvidkova ${ }^{1 *}$

\begin{abstract}
Background: The present study investigated plasma levels of gut-brain axis peptides ghrelin, obestatin, NPY and PYY after consumption of a high-carbohydrate (HC) and high-protein (HP) breakfast in patients with anorexia nervosa, bulimia nervosa and in healthy controls. These peptides play an important role in regulation of energy homeostasis and their secretion is disturbed under condition of eating disorders. As various types of consumed macronutrients may induce different plasma hormone responses, so we examined these responses in women patients with eating disorders and compared them with those of healthy controls.

Methods: We examined plasma hormone responses to HC and HP breakfast in patients with AN ( $n=14$; age: $24.6 \pm 1.8$ years, BMl: $15.3 \pm 0.7)$, BN ( $n=15$; age: $23.2 \pm 1.7$ years, BMl: $20.5 \pm 0.9)$ and healthy controls $(n=14$; age: $24.9 \pm 1.4$ years, BMl: $21.1 \pm 0.8$ ). Blood samples were drawn from the cubital vein, the first blood drawn was collected before meal, and then 30, 60, 90, 120 and 150 min after breakfast consumption. Plasma hormone levels were determined by commercially available RIA kits.

Results: Fasting and postprandial plasma obestatin levels were significantly increased in both AN and BN patients, while plasma ghrelin levels were significantly increased in AN patients only. After breakfast consumption, plasma levels of ghrelin and obestatin decreased, although they were still above the range of values of healthy controls. Fasting NPY plasma levels were significantly increased in AN and BN patients and did not change postprandially. Fasting PYY levels were comparable in AN, BN and healthy controls, but postprandially significantly increased after HP breakfast in AN and BN patients. Different reactions to breakfast consumption was found for ghrelin and PYY among investigated groups, while for obestatin and NPY these reactions were similar in all groups.

Conclusions: Significant increase of obestatin and NPY in AN and BN patients may indicate their important role as the markers of eating disorders. Different reactions of ghrelin and PYY to breakfast consumption among groups suggest that role of these hormones in regulation of energy homeostasis can be adjusted in dependence to acute status of eating disorder.
\end{abstract}

Keywords: Ghrelin, Obestatin, NPY, PYY, Anorexia nervosa, Bulimia nervosa, High-carbohydrate breakfast, High-protein breakfast

\footnotetext{
* Correspondence: jnedvidkova@endo.cz

'Institute of Endocrinology, Narodni 8, 11694 Prague 1, Czech Republic

Full list of author information is available at the end of the article
} 


\section{Background}

Food intake and appetite are controlled by hypothalamus, where nucleus arcuatus (ARC) through interaction of peripheral hormonal and metabolic signals control all processes relating to energy balance. Peptides of gutbrain axis play a pivotal role in regulation of energy homeostasis and their secretion is disturbed under condition of eating disorders, including anorexia nervosa (AN) and bulimia nervosa (BN). These psychiatric and somatic diseases are characterized by abnormal eating behaviour and imbalance in energy homeostasis. Neuropeptide Y (NPY) has a number of important functions in regulation of appetite and energy homeostasis [1]. NPY neurons in the hypothalamic ARC play a central role in stimulation of feeding, they sense and integrate peripheral and central signals, including ghrelin and leptin [2]. Ghrelin is a peptide produced mainly by stomach, which as appetite-stimulating hormone transmits changes in food intake to the central nervous system [3]. The effect of ghrelin is related to the antagonism of the inhibitory effect of leptin on hypothalamic NPY production [4-6]. A novel peptide hormone obestatin, derived from the same gene as ghrelin, has been initially postulated to antagonize ghrelin actions on energy homeostasis and gastrointestinal functions [7-9], however the most of subsequent studies could not confirm its reported anorexigenic effects [10-13]. Plasma levels of these hormones, both fasting and postprandial, were investigated in AN and BN patients. Most of previous studies reported increased fasting plasma ghrelin levels in AN patients [3,14-17] and recent studies also presented increased fasting plasma obestatin levels in these patients $[17,18]$. In $\mathrm{BN}$ patients were reported either no changes in fasting ghrelin or increased plasma ghrelin levels, compared to healthy controls $[15,19,20]$. Monteleone et al. (2008) did not find any increase in fasting obestatin plasma levels in BN patients [17]. However, in our previous study, we found increased fasting plasma ghrelin levels only in AN patients while obestatin levels were elevated in both group of patients with $\mathrm{AN}$ and $\mathrm{BN}$ [21]. Peptide YY (PYY) is a member of the pancreatic polypeptide family, which has been reported to reduce food intake [22]. It is suggested that peripheral PYY acts as a satiety signal regulating the termination of individual meals, partially by decreasing the production of the hungerstimulating peptide ghrelin [17]. Fasting PYY levels have been reported to be low in healthy people [23,24], normal [25] or increased [26-28] in AN patients and normal in $\mathrm{BN}$ patients $[20,23]$. Leptin is a peptide hormone, secreted mainly by adipose tissue, which influences longterm energy homeostasis. Decreased leptin levels were measured in AN patients with undernutrition [19,29].

All introduced hormones are involved in regulation of food intake and energy homeostasis, either in acute (ghrelin, obestatin, PYY) or long-term changes (leptin, NPY). The effect of specific macronutrients (carbohydrates, proteins, fat) on secretion of above mentioned hormones has been partially investigated in humans. However, results reported in individual studies are very different, especially in studies aimed to patients with eating disorders. Prince et al. compared the results of studies concerned to gut hormone levels in patients with eating disorders, with general conclusion that these patients had higher baseline concentrations of ghrelin and PYY. No differences were found in release of these hormones to a standardized test meal, when compared to healthy controls [30].

To our knowledge, no study has measured simultaneously pre- and postprandial secretion of ghrelin, obestatin, NPY, PYY and leptin in patients with $\mathrm{AN}$ and $\mathrm{BN}$. Therefore the aim of present study was to investigate plasma levels of these hormones after consumption of two meals with different content of macronutrients (high-protein and high-carbohydrate breakfast) in patients with $\mathrm{AN}, \mathrm{BN}$ and healthy women. We investigated if plasma hormone responses are different after consumption of high-protein and high-carbohydrate breakfast within the observed groups. Simultaneously, we compared if plasma hormone responses to the same $\mathrm{HC} / \mathrm{HP}$ breakfast differs among patients with $\mathrm{AN}, \mathrm{BN}$ and healthy controls.

\section{Methods}

\section{Subjects}

This study was performed in accordance with the Declaration of Helsinki and was approved by Ethic Committee of Institute of Endocrinology in Prague. All participants undersigned informed consent prior to the study. Fourteen patients with $\mathrm{AN}$, both restrictive and purgative type (age: $24.6 \pm 1.8$ years, BMI: $15.3 \pm 0.7$ ), fifteen women with BN (age: $23.2 \pm 1.7$ years, BMI: $20.5 \pm 0.9$ ) and fourteen healthy controls (age: $24.9 \pm 1.4$ years, BMI: $21.1 \pm 0.8 \mathrm{~kg} / \mathrm{m}^{2}$ ) were enrolled in the study. Healthy controls $(C)$ were recruited from university students, age-matched to $\mathrm{AN}$ and $\mathrm{BN}$ patients. They had no history of eating disorders, had normal electrocardiogram (ECG), blood count, liver and renal functions. Blood tests and physical examination were conducted before the test. All healthy women had regular menstrual cycle and were in follicular phase of the cycle at the time of study. AN and BN patients were diagnosed according to the $4^{\text {th }}$ edition of the Diagnostic and Statistical Manual of Mental Disorders, American Psychiatric Association, 1994. All AN and BN patients were clinically stable and in relatively good health, except for their eating disorder and amenorrhea. All patients were investigated after 1 week of hospitalization at the Department of Psychiatry at Charles University, Prague. Blood tests conducted before initiation of the study confirmed normal 
values for blood count, fasting blood glucose, liver and renal functions.

Participants were recommended to avoid vigorous physical activity during the 14-hour period before blood samplings. All subjects consumed a standardized dinner at 6.00 PM and were then asked to fast overnight. Reported duration of sleep in the night preceding blood sampling was comparable in all studied groups. All participants were admitted to the Institute of Endocrinology at 7.30 AM. The study lasted about 3.5 hours and the protocol consisted of high-carbohydrate breakfast consumption and blood withdrawals. One week later, all patients were investigated again and they received high-protein breakfast with the same study protocol. Body composition was measured using method of bioimpedance [Tanita, Japan] together with other physical examination before the beginning of both breakfasts.

\section{Study design}

Each participant received a high-carbohydrate breakfast (HC) with a total energy content of $1604 \mathrm{~kJ}$, consisting of $81.9 \mathrm{~g}$ carbohydrates, $8.8 \mathrm{~g}$ proteins and $3.4 \mathrm{~g}$ fats in the form of a white bread roll $(90 \mathrm{~g})$ and strawberry jam $(50 \mathrm{~g})$ [21]. One week later, each participant received a high-protein breakfast (HP) with a total energy content of $1350 \mathrm{~kJ}$, consisting of $41.3 \mathrm{~g}$ proteins, $16.3 \mathrm{~g}$ carbohydrates and $8.1 \mathrm{~g}$ fat in the form of a cottage cheese (150 g), chicken ham (75 g) and wheat store-bread (15 g). In addition, the subjects consumed $250 \mathrm{ml}$ of fruit tea without sugar or other sweetener together with the meal. Participants had 15 minutes time- limit to consume their meal. Blood samples were drawn from the cubital vein using an intravenous cannula, the first blood drawn was collected before meal, and then 30, 60, 90, 120 and $150 \mathrm{~min}$ after breakfast consumption. Blood samples were collected into chilled polypropylene tubes containing $\mathrm{Na}_{2}$ EDTA and antilysin. Plasma was immediately separated by 15 -min centrifugation at $5^{\circ} \mathrm{C}$ and stored at $-70^{\circ} \mathrm{C}$ until being assayed [21].

\section{Analytical measurements}

Total plasma ghrelin and NPY were determined by commercially available RIA kits (Linco Research, Inc., St. Charles, Missouri, U.S.A.). The intra- and interassay for total ghrelin was $6.4 \%$ and $16.3 \%$, sensitivity was $93 \mathrm{pg} /$ $\mathrm{mL}$, for NPY the intra- and interassay was $5.0 \%$ and $8.4 \%$ respectively, sensitivity was $3 \mathrm{pmol} / \mathrm{L}$. Plasma obestatin was measured by a commercial RIA kit (Phoenix Pharmaceuticals Inc., Belmont, CA, U.S.A.), the intraand interassay variability was $5.0 \%$ and $14.2 \%$, respectively, sensitivity was $50 \mathrm{pg} / \mathrm{mL}$. Plasma PYY was determined by commercially available RIA kit (Linco
Research, Inc., St. Charles, Missouri, U.S.A.). The intraand interassay for total PYY was 5.8\% and $13.9 \%$, sensitivity was $72 \mathrm{pg} / \mathrm{mL}$.

\section{Statistical data analysis}

The dependence of metric variables on factors was evaluated using repeated measures ANOVA model consisting of subject factor, repeated and non-repeated factors and interaction between factors. Least significant difference multiple comparisons followed the ANOVA testing. The level of statistical significance $\mathrm{P}<0.05$ was chosen for both ANOVA and multiple comparisons. Due to non-Gaussian data distribution in all dependent variables these underwent power transformations to attain distributional symmetry and a constant variance both in the data and residuals. Data transformation and analysis of variance was performed using Statgraphics Centurion version XV software (Statpoint Inc, Herndon, Virginia, USA). The relationships between variables were evaluated using multivariate regression after transformation of variables to symmetry and constant variance. The statistical software SIMCA v. 12.0 from Umetrics (Umeå, Sweden) was used for data analysis.

\section{Results}

The fasting plasma levels of ghrelin, obestatin, NPY and PYY and their postprandial responses after highcarbohydrate (HC) and high-protein (HP) breakfast consumption are presented in Figures 1, 2, 3 and 4 for all investigated groups.

\section{Ghrelin}

Fasting and postprandial plasma ghrelin levels were significantly increased in AN patients compared to the controls and BN patients. After both types of breakfast, plasma ghrelin levels significantly decreased, with minimum at 90 min after $\mathrm{HC}$ breakfast and $30 \mathrm{~min}$ after HP breakfast. Factor "breakfast" was not significant in AN patients, but interaction "breakfast" $\mathrm{x}$ "time (stage of the meal test)" showed different course of ghrelin in time after $\mathrm{HC}$ and HP breakfast. In BN patients, fasting and postprandial levels of ghrelin were comparable to values of healthy controls. After both types of breakfast, plasma ghrelin levels decreased, however this decrease was significant only after HC breakfast. Minimum ghrelin values were reached $90 \mathrm{~min}$ after $\mathrm{HC}$ breakfast and 30 min after HP breakfast (equally, as in AN patients). The course of ghrelin after both types of breakfast was different after $\mathrm{HC}$ and $\mathrm{HP}$ breakfast in $\mathrm{BN}$ patients. In healthy control women, plasma ghrelin levels significantly decreased after both types of breakfast with minimum at $120 \mathrm{~min}$ after $\mathrm{HC}$ breakfast and $60 \mathrm{~min}$ after HP breakfast. The factor "breakfast" was significant. As 


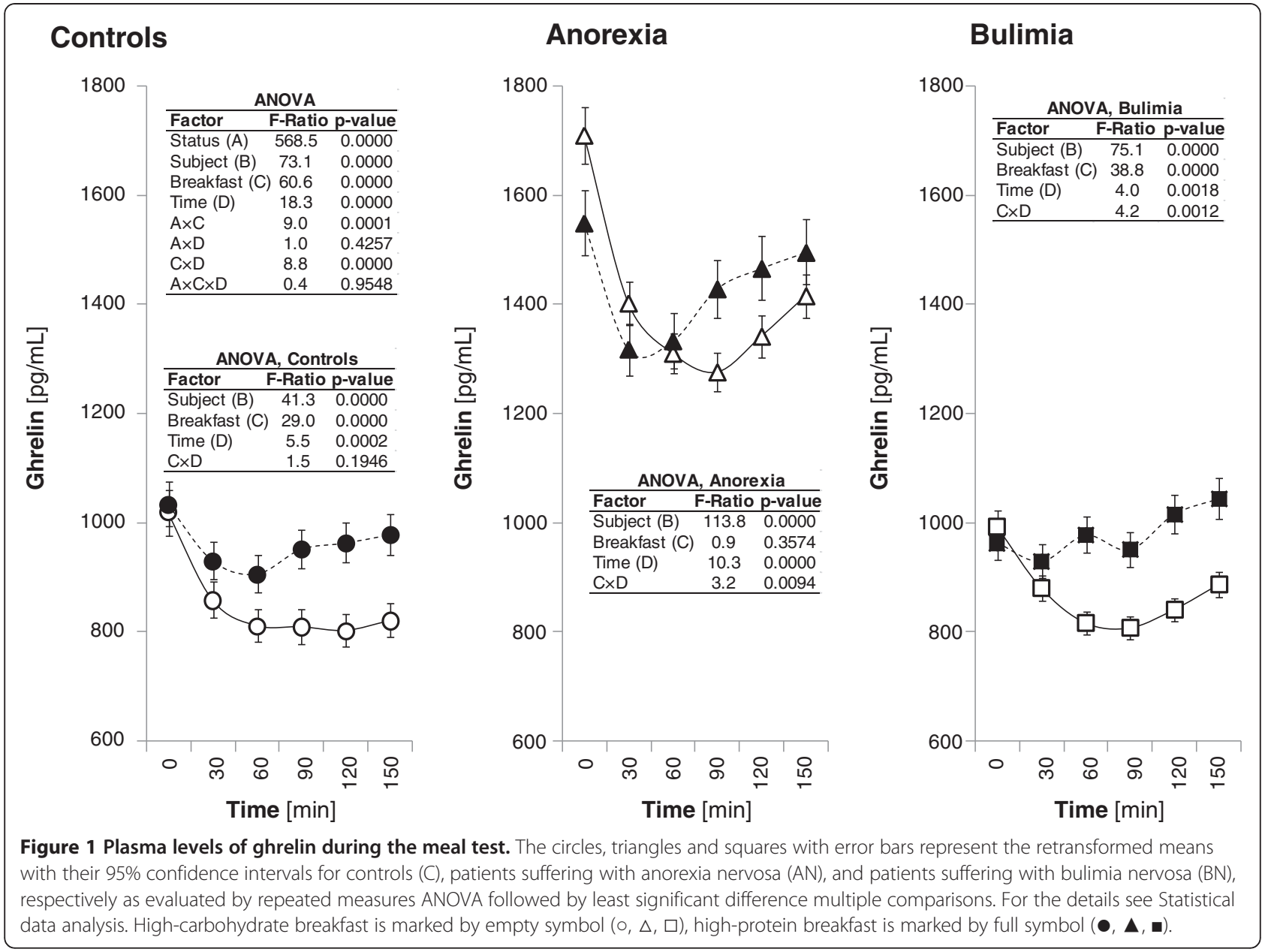

documented by significant interaction "status" $\mathrm{x}$ "breakfast" in overall ANOVA, the ghrelin reaction was different after $\mathrm{HC}$ and $\mathrm{HP}$ breakfast consumption among investigated groups.

\section{Obestatin}

Fasting plasma obestatin levels were found significantly increased in both $\mathrm{AN}$ and $\mathrm{BN}$ patients compared to the controls. The highest basal values were observed in AN patients, similarly as plasma ghrelin values. In these patients plasma obestatin levels decreased significantly after both types of breakfast, with minimum at $90 \mathrm{~min}$ after $\mathrm{HC}$ and 30 min after HP breakfast. Neither factor "breakfast" nor interaction "breakfast" x "time" were significant in AN patients, and therefore no difference was found in ghrelin reaction in time after $\mathrm{HC}$ and $\mathrm{HP}$ breakfast consumption. In $\mathrm{BN}$ patients, plasma obestatin levels decreased significantly after both types of breakfast, with minimum values at $90 \mathrm{~min}$ after $\mathrm{HC}$ breakfast and $150 \mathrm{~min}$ after HP breakfast. As documented by significant factor "breakfast" and interaction "breakfast" $\mathrm{x}$ "time", course of obestatin after both types of breakfast was different in $\mathrm{BN}$ patients. In healthy control group, plasma obestatin levels also significantly decreased after both $\mathrm{HC}$ and HP breakfast consumption and course of obestatin was different in time. The obestatin reaction after HC and HP breakfast was similar in all groups, although plasma levels had different range of values, as documented by interaction "status" x "breakfast" in overall ANOVA.

\section{NPY}

Fasting and postprandial plasma levels of NPY were significantly increased in $\mathrm{AN}$ and $\mathrm{BN}$ patients compared to the controls. No changes were found postprandially in AN patients after both types of breakfast, but in BN patients and healthy controls plasma NPY decreased after $\mathrm{HC}$ breakfast. After HP breakfast consumption no significant changes were found. However, as indicated by interaction "breakfast" $\mathrm{x}$ "time", the course of NPY after $\mathrm{HC}$ and $\mathrm{HP}$ breakfast consumption was not significantly different in all investigated groups. Also no differences were found in NPY reaction to breakfasts consumption among investigated groups. 


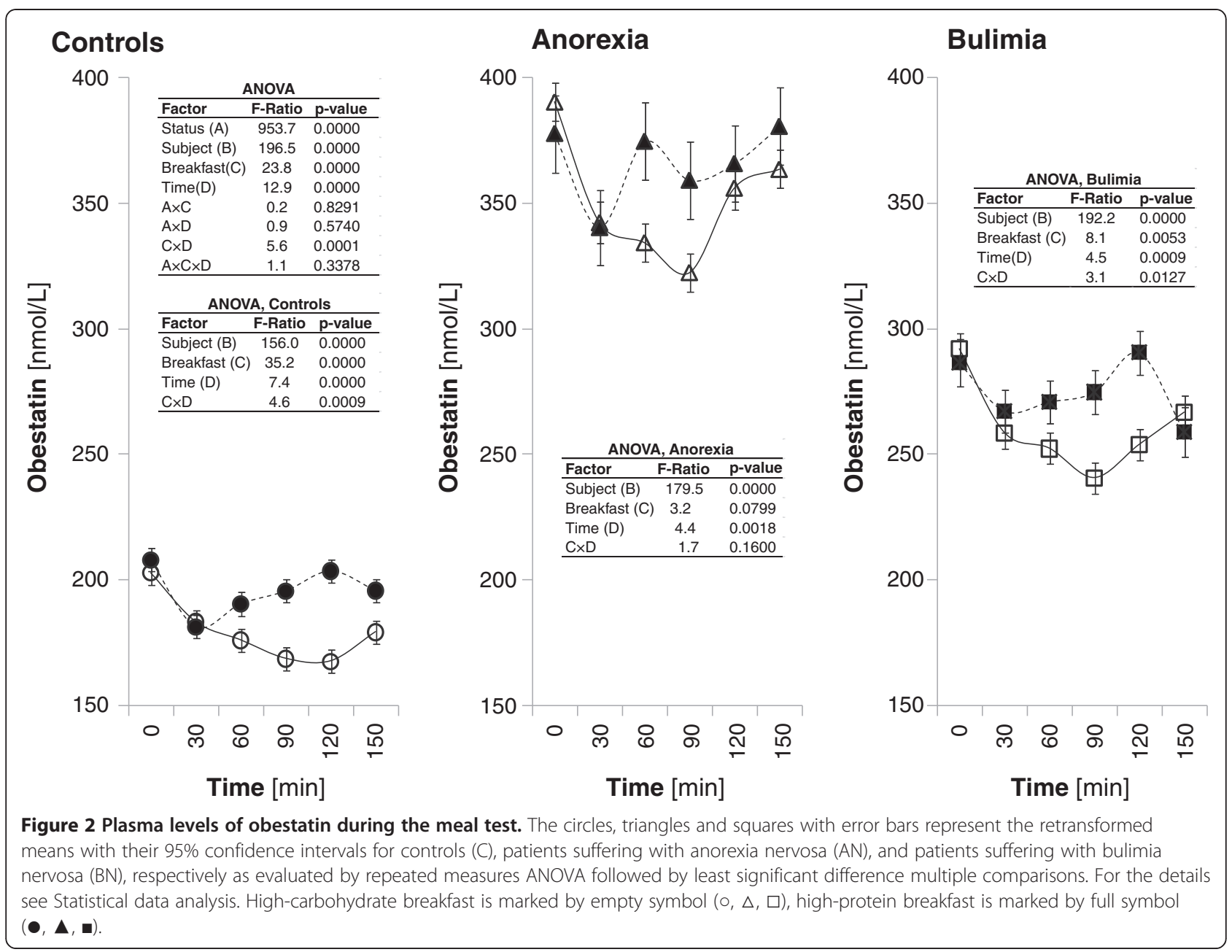

PYY

Fasting plasma levels of PYY were found in similar range of values for all investigated groups. However, significant differences were found in postprandial responses of PYY to $\mathrm{HC}$ and $\mathrm{HP}$ breakfast in patients with $\mathrm{AN}$ and $\mathrm{BN}$ compared to the controls. In AN and BN groups, plasma PYY levels reached significantly higher values after HP breakfast compared to $\mathrm{HC}$ breakfast, with maximum in $120 \mathrm{~min}$ for AN and $90 \mathrm{~min}$ for BN. In healthy control group, postprandial increase was also observed after HP breakfast, however this increase was not significant and reached values were significantly lower than plasma PYY levels in AN and BN groups. As documented by significant interaction "status" x "breakfast" in overall ANOVA, the PYY course after HC and HP breakfast was different among investigated groups.

\section{Leptin}

Basal plasma levels of leptin were found significantly lower in $\mathrm{AN}$ and $\mathrm{BN}$ patients compared to healthy women. We found no changes in leptin levels postprandially either after $\mathrm{HC}$ or HP breakfast consumption in all investigated groups.

\section{Correlations}

Status of anorexia nervosa was found to be positively correlated with plasma levels of ghrelin, obestatin, NPY and PYY and negatively correlated with BMI, percent of body fat and weight. Status of bulimia nervosa was found to be positively correlated with plasma levels of NPY, obestatin and PYY, and negatively with leptin levels.

\section{Discussion}

This study was designed to investigate the plasma responses of ghrelin, obestatin, NPY and PYY after highcarbohydrate and high-protein breakfast consumption in $\mathrm{AN}$ and BN patients and in healthy women. We found fasting plasma obestatin levels significantly increased in $\mathrm{AN}$ and $\mathrm{BN}$ patients, while ghrelin levels were increased only in AN patients. Postprandially, we observed significant decrease in plasma ghrelin levels after both types of breakfast in all investigated groups. Different plasma 


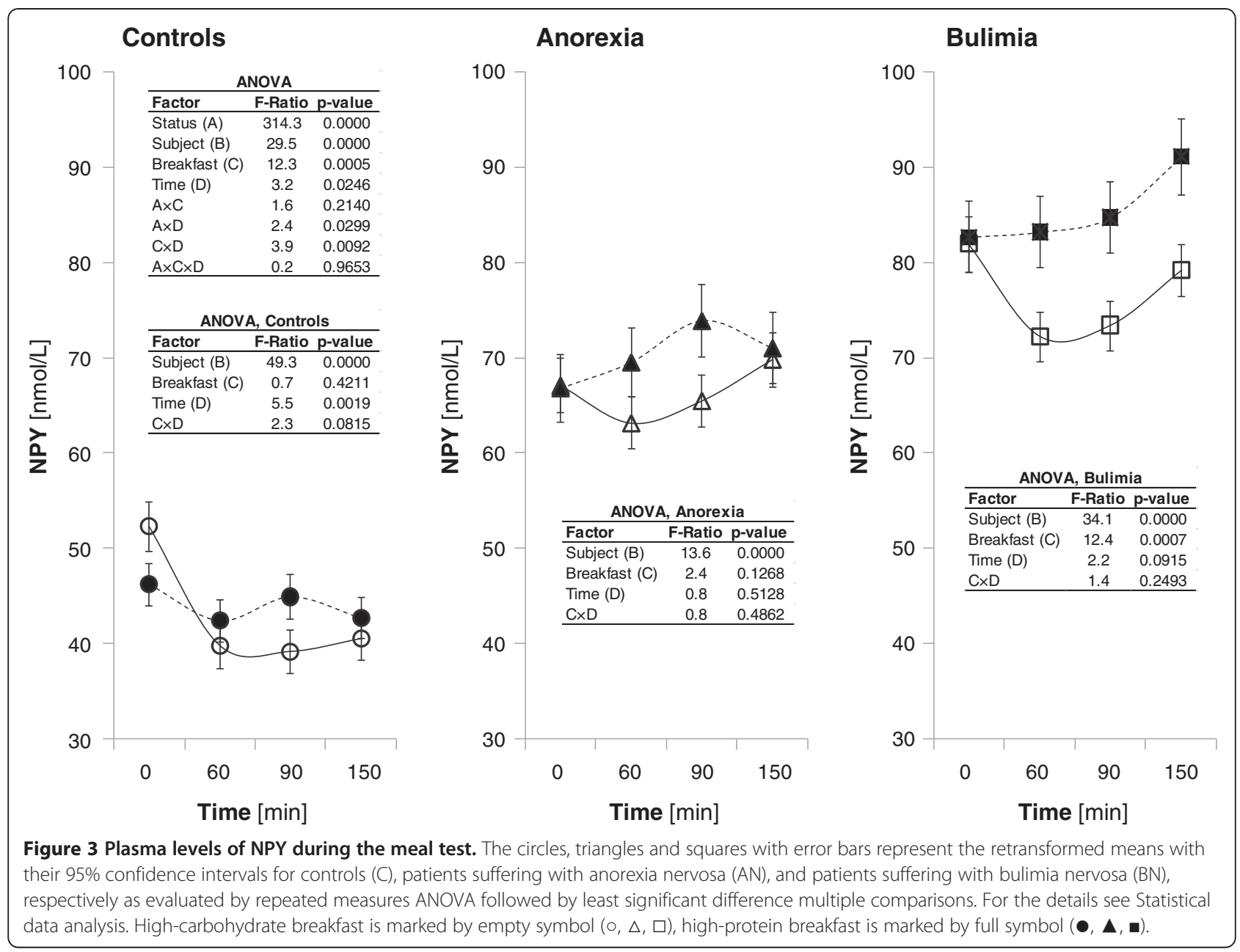

response of ghrelin to $\mathrm{HC}$ and $\mathrm{HP}$ breakfast was observed in all investigated groups. Regarding obestatin levels, they also decreased postprandially after both types of breakfast in all investigated groups. In $\mathrm{BN}$ patients and healthy controls the reaction of obestatin was different to $\mathrm{HC}$ and $\mathrm{HP}$ breakfast, however in AN patients no difference was found.

Our results for fasting ghrelin and obestatin levels in AN patients and healthy controls are consistent with present findings of other authors. Recent studies showed increased plasma obestatin and ghrelin levels in AN patients [18,26,31]. Monteleone et al. (2008) found increased fasting plasma obestatin levels in AN patients, however in $\mathrm{BN}$ patients obestatin levels were comparable to healthy controls [17]. In our previous study, we demonstrated for the first time that plasma obestatin levels significantly decrease after consumption of a highcarbohydrate breakfast in a similar way as ghrelin levels in healthy women [32]. Results of present study correspond with our previous findings and were confirmed also for $\mathrm{AN}$ and $\mathrm{BN}$ patients, independently on the type of consumed breakfast. This positive relationship of obestatin and ghrelin in postprandial period indicates that these two cleavage products of preproghrelin act in a similar way to increase food intake. Comparison of hormone responses to $\mathrm{HC}$ and $\mathrm{HP}$ breakfast confirmed mostly different reaction of these hormones in time to the type of macronutrient. During comparison of groups, similar reactions to food intake were confirmed for obestatin in $\mathrm{AN}$ patients, $\mathrm{BN}$ patients and healthy women, however the values of plasma obestatin were different. Contrary, ghrelin responses to food intake were different among groups.

NPY plays a central role in stimulation of feeding and regulation of energy homeostasis. We found fasting plasma levels of NPY significantly higher in AN and BN patients, when compared to the healthy controls. This finding is partially in accordance with studies of other authors, where NPY levels were reported to be both increased [33,34] and decreased [35] in AN patients. Plasma NPY levels in our study showed no difference in time to $\mathrm{HC}$ or HP breakfast in all groups. Overall analysis for all groups showed that reaction of plasma NPY to $\mathrm{HC}$ and HP breakfast consumption was not significantly 


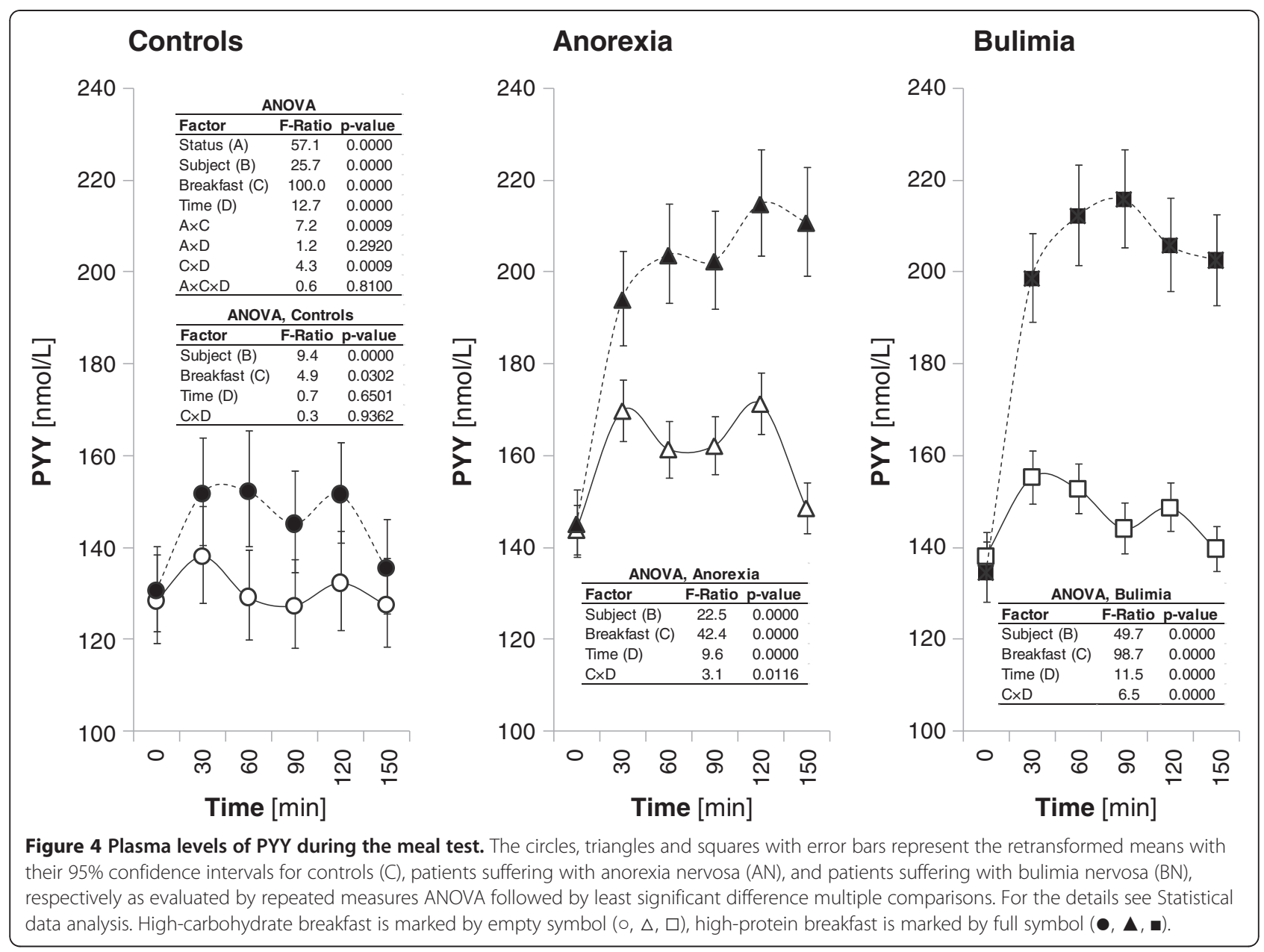

different among groups. To date, no study has reported any response of NPY to carbohydrate and protein meal in healthy controls or $\mathrm{AN}$ and $\mathrm{BN}$ patients, therefore we have no possibility to compare our findings. Production of leptin correlates positively with adipose tissue mass and circulating leptin levels, and thus reflects energy stores of organism. In our study fasting plasma leptin levels were significantly lower in AN and BN patients and no changes in were found postprandially.

Circulating PYY levels are low in the fasting state and rapidly increase postprandially when two forms, PYY1-36 and PYY3-36 are released to circulation. In our study we observed significant increase in postprandial plasma levels in $\mathrm{AN}$ and $\mathrm{BN}$ patients after $\mathrm{HP}$ breakfast, much higher than those in healthy controls. This suggests strong influence of macronutrient type to postprandial secretion of PYY in patients with eating disorders. These results partially correspond with study of Nakahara et al. (2007), where PYY3-36 plasma levels were increased after standard meal consumption in both AN patients and healthy controls [26]. Our results are also partly in accordance with review of
Prince at al. (2009), where patients with eating disorders had higher baseline concentrations of PYY and ghrelin [30]. In contrast, in study of Stock et al. (2005) PYY increased significantly in the controls, but not in AN patients [36]. In $\mathrm{BN}$ patients, initial studies reported normal plasma levels of PYY. Recently, two independent research groups have reported a blunted PYY3-36 response to food ingestion in symptomatic $\mathrm{BN}$ women together with a decreased response of ghrelin $[20,23]$. Both studies have shown a negative correlation between meal-induced PYY increase and ghrelin decrease, confirming a negative interaction of PYY3-36 with ghrelin [17].

Correlations between status of eating disorder and investigated hormones were evaluated. As status of anorexia nervosa was found to be positively correlated with plasma levels of ghrelin, obestatin, NPY and PYY, we suppose that all these hormones are included in pathology of eating disorder and their levels are changed probably as a consequence of eating disorder. Status of bulimia nervosa was found to be positively correlated with plasma levels of NPY, obestatin and PYY and 
negatively with leptin levels, which suggest a lot of common with status of anorexia nervosa, at least regarding behavior of plasma hormones and disturbed regulation of energy homeostasis.

\section{Conclusions}

In conclusion, we demonstrated that significant differences exist in hormonal responses of ghrelin, obestatin and PYY to a high-carbohydrate and high-protein breakfast consumption within investigated groups. Increased fasting plasma levels of NPY and obestatin were confirmed in AN and BN groups, which suggest a role of these hormones as a markers for eating disorders. PYY levels reached much higher values after high-protein breakfast in AN and BN patients, indicating an important role of ingested macronutrient to plasma levels of this hormone. Different reactions of ghrelin and PYY to breakfast consumption were found among investigated groups.

\section{Competing interests}

The authors declare that there is no conflict of interests.

\section{Authors' contributions}

DS carried out research, contributed on analytical measurements and wrote the article. JK participated on research and analytical measurements. HP selected and provided hospitalized pacients with AN and BN suitable for the study. VH contributed in writing of the article. HK examined all participants prior to the study. MH performed statistical data analysis. JN designed research, led the grant project, contributed in writing of the article. All authors read and approved the final manuscript.

\section{Acknowledgements}

This study was supported by the grant NR/9158-3 provided by IGA Ministry of Health, Czech Republic, and by the project of Ministry of Health (Czech Republic) for conceptual development of research organization 00023761 (Institute of Endocrinology, Prague). We thank Diana Riegerova, Nada Prochazkova, Miloslava Jungmannova and Romana Bajtlova for their technical assistance.

\section{Author details}

${ }^{1}$ Institute of Endocrinology, Narodni 8, 11694 Prague 1, Czech Republic ${ }^{2}$ First Faculty of Medicine, Charles University, Prague, Czech Republic. ${ }^{3}$ Department of Anthropology and Human Genetics, Charles University, Prague, Czech Republic. ${ }^{4}$ Faculty of Science, Department of Anthropology and Human Genetics, Charles University, Vinicna 7, 12844 Prague 2, Czech Republic. ${ }^{5}$ First Faculty of Medicine, Psychiatric Department, Ke Karlovu 11, 120 00, Prague 2, Czech Republic.

Received: 20 October 2011 Accepted: 3 May 2012

Published: 8 June 2012

\section{References}

1. Yang K, Guan H, Arany E, Hill DJ, Cao X: Neuropeptide $Y$ is produced in visceral adipose tissue and promotes proliferation of adipocyte precursor cells via the Y1 receptor. FASEB J 2008, 22(7):2452-2464.

2. Wynne K, Stanley S, McGowan B, Bloom S: Appetite control. J Endocrinol 2005, 184(2):291-318.

3. Otto B, Tschöp M, Frühauf E, Heldwein W, Fichter M, Otto C, Cuntz U: Postprandial ghrelin release in anorectic patients before and after weight gain. Psychoneuroendocrinology 2005, 30:577-581.

4. Shintani M, Ogawa Y, Ebihara K, Aizawa-Abe M, Miyanaga F, Takaya K, Hayashi T, Inoue G, Hosoda K, Kojima M, Kangawa K, Nakao K: Ghrelin, an endogenous growth hormone secretagogue, is a novel orexigenic peptide that antagonizes leptin action through the activation of hypothalamic neuropeptide Y/Y1 receptor pathway. Diabetes 2001, 50(2):227-232

5. Nakazato M, Murakami N, Date Y, Kojima M, Matsuo H, Kangawa K, Matsukura S: A role for ghrelin in the central regulation of feeding. Nature 2001, 409(6817):194-198.

6. Seoane LM, Al-Massadi O, Lage M, Dieguez C, Casanueva FF: Ghrelin: from a GH-secretagogue to the regulation of food intake, sleep and anxiety. Pediatr Endocrinol Rev 2004, 1(Suppl 3):432-437.

7. Zhang JV, Ren PG, Avsian-Kretchmer O, Luo CW, Rauch R, Klein C, Hsueh AJ: Obestatin, a peptide encoded by the ghrelin gene, opposes ghrelin's effects on food intake. Science 2005, 310:996-999.

8. Tremblay F, Perreault M, Klaman LD, Tobin JF, Smith E, Gimeno RE: Normal food intake and body weight in mice lacking the $G$ protein-coupled receptor GPR39. Endocrinology 2007, 148(2):501-506.

9. Carlini VP, Schiöth HB, Debarioglio SR: Obestatin improves memory performance and causes anxiolytic effects in rats. Biochem Biophys Res Commun 2007, 352(4):907-912.

10. Gourcerol G, Million M, Adelson DW, Wang Y, Wang L, Rivier J, St-Pierre DH, Taché Y: Lack of interaction between peripheral injection of CCK and obestatin in the regulation of gastric satiety signaling in rodents. Peptides 2006, 27(11):2811-2819.

11. Holst B, Egerod KL, Schild E, Vickers SP, Cheetham S, Gerlach LO, Storjohann $L$, Stidsen CE, Jones R, Beck-Sickinger AG, Schwartz TW: GPR39 signaling is stimulated by zinc ions but not by obestatin. Endocrinology 2007, 148(1):13-20.

12. Nogueiras R, Pfluger P, Tovar S, Arnold M, Mitchell S, Morris A, Perez-Tilve D, Vázquez MJ, Wiedmer P, Castañeda TR, DiMarchi R, Tschöp M, Schurmann A, Joost HG, Williams LM, Langhans W, Diéguez C: Effects of obestatin on energy balance and growth hormone secretion in rodents. Endocrinology 2007, 148(1):21-26.

13. Yamamoto D, Ikeshita N, Daito R, Herningtyas EH, Toda K, Takahashi K, lida K, Takahashi Y, Kaji H, Chihara K, Okimura Y: Neither intravenous nor intracerebroventricular administration of obestatin affects the secretion of GH, PRL, TSH and ACTH in rats. Regul Pept 2007, 138(2-3):141-144.

14. Nedvidkova J, Krykorkova I, Bartak V, Papezova H, Gold PW, Alesci S, Pacak K: Loss of mealinduced decrease in plasma ghrelin levels in patients with anorexia nervosa. J Clin Endocrinol Metab 2003, 88:1678-1682.

15. Troisi A, Di Lorenzo G, Lega I, Tesauro M, Bertoli A, Leo R, lantorno M, Pecchioli C, Rizza S, Turriziani M, Lauro R, Siracusano A: Plasma ghrelin in anorexia, bulimia, and binge-eating disorder: relations with eating patterns and circulating concentrations of cortisol and thyroid hormones. Neuroendocrinology 2005, 81(4):259-266.

16. Janas-Kozik M, Krupka-Matuszczyk I, Malinowska-Kolodziej I, Lewin-Kowalik J: Total ghrelin plasma level in patients with the restrictive type of anorexia nervosa. Regul Pept 2007, 140(1-2):43-46.

17. Monteleone P, Serritella C, Martiadis V, Scognamiglio P, Maj M: Plasma obestatin, ghrelin, and ghrelin/obestatin ratio are increased in underweight patients with anorexia nervosa but not in symptomatic patients with bulimia nervosa. J Clin Endocrinol Metab 2008, 93:4418-4421.

18. Germain N, Galusca B, Grouselle D, Frere D, Tolle V, Zizzari P, Lang F, Epelbaum J, Estour B: Ghrelin/obestatin ratio in two populations with low bodyweight: Constitutional thinness and anorexia nervosa. Psychoneuroendocrinology 2009, 34:413-419.

19. Tanaka M, Nakahara T, Kojima S, Nakano T, Muranaga T, Nagai N, Ueno H, Nakazato M, Nozoe S, Naruo T: Effect of nutritional rehabilitation on circulating ghrelin and growth hormone levels in patients with anorexia nervosa. Regul Pept 2004, 122(3):163-168.

20. Kojima S, Nakahara T, Nagai N, Muranaga T, Tanaka M, Yasuhara D, Masuda A, Date $Y$, Ueno H, Nakazato M, Navuo T: Altered ghrelin and peptide YY responses to meals in bulimia nervosa. Clin Endocrinol 2005, 62:74-78.

21. Sedlackova D, Kopeckova J, Papezova H, Vybiral S, Kvasnickova H, Hill M, Nedvidkova J: Changes of plasma obestatin, ghrelin and NPY in anorexia and bulimia nervosa patients before and after a high-carbohydrate breakfast. Physiol Res 2011, 60(1):165-173.

22. Batterham RL, Cowley MA, Small CJ, Herzog H, Cohen MA, Dakin CL, Wren AM, Brynes AE, Low MJ, Ghatei MA, Cone RD, Bloom SR: Gut hormone PYY (3-36) physiologically inhibits food intake. Nature 2002, 418(6898):650-654.

23. Monteleone P, Fabrazzo M, Tortorella A, Martiadis V, Serritella C, Maj M: Circulating ghrelin is decreased in non-obese and obese women with binge eating disorder as well as in obese non-binge eating women, but 
not in patients with bulimia nervosa. Psychoneuroendocrinology 2005, 30(3):243-250

24. Batterham RL, Bloom SR: The gut hormone peptide YY regulates appetite. Ann N Y Acad Sci 2003, 994:162-168.

25. Stock S, Leichner P, Wong AC, Ghatei MA, Kieffer TJ, Bloom SR, Chanoine JP: Ghrelin, peptide YY, glucose-dependent insulinotropic polypeptide, and hunger responses to a mixed meal in anorexic, obese, and control female adolescents. J Clin Endocrinol Metab 2005, 90(4):2161-2168.

26. Nakahara T, Kojima S, Tanaka M, Yasuhara D, Harada T, Sagiyama K, Muranaga T, Nagai N, Nakazato M, Nozoe S, Naruo T, Inui A: Incomplete restoration of the secretion of ghrelin and PYY compared to insulin after food ingestion following weight gain in anorexia nervosa. J Psychiatr Res 2007, 41(10):814-820.

27. Misra M, Miller KK, Tsai P, Gallagher K, Lin A, Lee N, Herzog DB, Klibanski A: Elevated peptide YY levels in adolescent girls with anorexia nervosa. J Clin Endocrinol Metab 2006, 91(3):1027-1033.

28. Pfluger PT, Kampe J, Castaneda TR, Vahl T, D'Alessio DA, Kruthaupt T, Benoit SC, Cuntz U, Rochlitz HJ, Moehlig M, Pfeiffer AF, Koebnick C, Weickert MO, Otto B, Spranger J, Tschöp MH: Effect of human body weight changes on circulating levels of peptide YY and peptide YY3-36. J Clin Endocrinol Metab 2007, 92(2):583-588.

29. Misra M, Miller KK, Kuo K, Griffin K, Stewart V, Hunter E, Herzog DB, Klibanski A: Secretory dynamics of leptin in adolescent girls with anorexia nervosa and healthy adolescents. Am J Physiol Endocrinol Metab 2005, 289(3):E373-E381.

30. Prince AC, Brooks SJ, Stahl D, Treasure J: Systematic review and metaanalysis of the baseline concentrations and physiologic responses of gut hormones to food in eating disorders. Am J Clin Nutr 2009, 89(3):755-765.

31. Harada T, Nakahara T, Yasuhara D, Kojima S, Sagiyama K, Amitani H, Laviano A, Naruo T, Inui A: Obestatin, acyl ghrelin, and des-acyl ghrelin responses to an oral glucose tolerance test in the restricting type of anorexia nervosa. Biol Psychiatry 2008, 63:245-247.

32. Sedlackova D, Dostalova I, Hainer V, Beranova L, Kvasnickova H, Hill M, Haluzik M, Nedvidkova J: Simultaneous decrease of plasma obestatin and ghrelin levels after a high-carbohydrate breakfast in healthy women. Physiol Res 2008, 57(Suppl 1):S29-S37.

33. Escobar L, Freire JM, Espinosa R, Pajares M, Girón JA, Vázquez JM, Chover A, Carrasco M, Ortero J, Gavilán I, Segura E, Aguilar M: Determination of insulin, leptin and neuropeptide y by radioimmunoanalysis in patients with morbid obesity and anorexia nervosa after therapeutic intervention. Rev Esp Med Nucl 2002, 21(1):3-11.

34. Oświecimska J, Ziora K, Geisler G, et al: Prospective evaluation of leptin and neuropeptide $Y$ (NPY) serum levels in girls with anorexia nervosa. Neuro Endocrinol Lett 2005, 26:301-304.

35. Baranowska B, Wolinska-Witort E, Wasilewska-Dziubinska E, Roguski K, Chmielowska M: Plasma leptin, neuropeptide Y (NPY) and galanin concentrations in bulimia nervosa and in anorexia nervosa. Neuro Endocrinol Lett 2001, 22(5):356-358.

36. Stock S, Leichner P, Wong AC, Ghatei MA, Kieffer TJ, Bloom SR, Chanoine JP: Ghrelin, peptide YY, glucose-dependent insulinotropic polypeptide, and hunger responses to a mixed meal in anorexic, obese, and control female adolescents. J Clin Endocrinol Metab 2005, 90(4):2161.

doi:10.1186/1743-7075-9-52

Cite this article as: Sedlackova et al: Comparison of a high-carbohydrate and high-protein breakfast effect on plasma ghrelin, obestatin, NPY and PYY levels in women with anorexia and bulimia nervosa. Nutrition \& Metabolism 2012 9:52.

\section{Submit your next manuscript to BioMed Central and take full advantage of:}

- Convenient online submission

- Thorough peer review

- No space constraints or color figure charges

- Immediate publication on acceptance

- Inclusion in PubMed, CAS, Scopus and Google Scholar

- Research which is freely available for redistribution 